\title{
Инфографика или визуелно приповедање: перспективе у библиотекарству
}

\author{
Іелена Јовин \\ Библиотека Матице српске, Нови Сад \\ jovinj@bms.ns.ac.rs
}

\begin{abstract}
Сажетак
У раду се анализирају и истичу предности инфографике, све утицајније технике за визуелно сажимање статистичких података, рекламирање, образовање и графичко приповедање различитих прича са друштвено одговорном тематиком Разматра се њена примена у библиотекарству кроз описе неколико одабраних примера инфографика које ефектно представљају конкретне аспекте деловања библиотека на порталу Pinterest. Kaо прво, издвојено је графичко решење статистичког годишњег извештаја, затим једно упутство по фазама о информационој писмености за студенте и друго о коришћењу лисног каталога из 1930-тих година, а потом плакати који указују на појаву плагијаризма, промоцију сарадње библиотека са наставним кадром и корисну технику звану "пажљиво читање”. За библиотекаре који се заинтересују за дизајн инфографике понућене су смернице за израду ефектних решења по мишљењу три експерта: Едварда Тафтија, Рендија Крума и Истока Павловића. Указује се и на потребне алате и бесплатне платформе за дизајн. Циљ рада је да подстакне библиотекаре да размишљају о визуелним мотивима репрезентативности и маркетингу библиотека, буду креативни, а пре свега аутентични
\end{abstract}

Кључне речи: визуелизација података, сажимање података, статичка инфографика, визуелно приповедање, дизајнерске смернице, Pinterest, анализа садржаја, годишњи статистички извештај, информациона писменост, употреба лисног каталога, плагијаризам, сарадња библиотека са наставним кадром, „пажљиво читање”, визуелни библиотечки маркетинг, креативност

Увод

У библиотекама се свакодневно врши прикупљање различитих статистичких података као што су број учлањених корисника, информација о публикацијама из фонда, посета приређеној трибини, уложених књига, креираних записа у електронском каталогу; сазнају се, на пример, комплекснији резултати истраживања утицаја библиотеке на постигнуће ученика, ${ }^{1}$ или степен задовољства корисника; ту су и упутства како да се користи одређена библиотечка услуга, или се скреће пажња на феномене лажних вести, плагијаризма или већег научног значаја библиотечких услуга и извора над претрагама на интернету. Листа података и аспеката библиотечког пословања је подужа. Набројани подаци најчешће остају забележени у месечним и годишњим извештајима, или буду објављени у истраживачким радовима, али се из улоге корисника библиотеке поставља питање њиховог јасног, сажетог, прегледног, упечатљивог и допадљивог начина представљања. У овом тексту акценат је стављен на визуелне мотиве, графику и дизајн као средства којима се могу рекламирати библиотечки сервиси и услуге, повећати број учлањених корисника, посетилаца дигиталне библиотеке, или посетилаца осмишљеног програма. Зато ће бити представљена област инфографике, која је уједно и уметност графичког представљања података, производа и различитих идејних решења.

\footnotetext{
1 Linda Hofschire, "Let's Get Visual: Harnessing data visualization to demonstrate a library's impact", November $1^{\text {st }} 2016$, preuzeto 19. 10. 2020, https://americanlibrariesmagazine.org/2016/11/01/lets-get-visual-data-visualization/.
} 


\section{Доминација визуелног наратива и процват инфографике}

„Визуелно има предност над свим осталим чулима. Најефикасније учимо и памтимо путем слика, а не писаних или изговорених речи."

Џон Медина, Brain Rules²

У савременом сајбер окружењу уобичајена је појава преплављености корисника различитим информацијама: вестима, рекламама, мејловима, порукама, твитовима итд. Ради што лакше и брже конзумације, те многобројне информације потребно је сажети и пробрати. То је, између осталог, и разлог појаве доминације визуелног наратива над текстуалним, која има и релевантну физиолошку подлогу у функционисању људског можданог система због доминације чула вида над осталима. ${ }^{3}$ Томе у прилог иде и доказано својство људског памћења да се

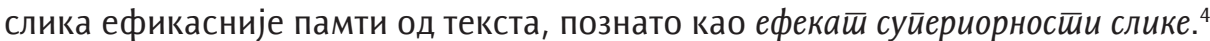

У датим околностима, поготово током последње деценије, велику популарност доживљава нова илустративна форма, информациона графика, или краће, инфографика. ${ }^{5}$ На домаћој научној сцени овој области није посвећена довољна пажња. Бобан Томић је један од ретких научника који се бавио анализом различитих илустративних жанрова и визуелном комуникацијом у области медија. Он истиче да се инфографика, због широког спектра могућности визуелизације садржаја и информативности, примењује и у другим областима људског деловања. При њеном дефинисању, он указује на то да се више пажње посвећује формалним и садржинским аспектима, а мање анализама ефеката у комуникацији. Просто речено, ради се о визуелизацији података и информација на начин који омогућује лаку, једноставну и прегледну конзумацију. ${ }^{6}$

Историјски развој инфографике може се пратити од праисторијских пећинских цртежа, попут оног из пећине Ласко, који објашњава „како уловити антилопу”, 7 или скице „Rosa Ursina sive Sol” немачког астронома Кристофа Шајнера с почетка 17. века, која представља дескриптивну шему кретања планета у Сунчевом систему. Прве модерне инфографике се, пак, појављују у виду различитих упутстава, презентација производа и просторних релација, као што су прикази метроа светских метропола.

У литератури из области инфографике често је навођен рад Едварда Тафтија, ${ }^{8}$ пионира теорије и праксе модерне графичке визуелизације података. Његов рад је превасходно усмерен на графичко представљање статистичких података у виду једноставних тачака, линија, координатних система, бројева, симбола, речи, сенки и боја, као и сложенијих дизајнерских решења попут мапа, временских серија, дијаграма, мултиваријантних приказа и статистичких табела. За Тафтија је инфографика превасходно сложен спој уметничког дизајна, емпиријске статистике и математике. По њему је вештина дизајна у томе да се конзумент подстакне на размишљање о суштини, да информације буду веродостојно приказане, мноштво бројева сведе на мали простор,

\footnotetext{
2 Edward R. Tufte, The visual Display of Quantitative Information (Cheshire, Connecticut: Graphic Press, 2001), [XX], preuzeto 15. 10. 2020, http://www.edwardtufte.com/.

${ }^{3}$ Истраживања показују да је у визуелну обраду укључено 50-80\% мозга. - Randy Krum, Cool Infographics: Effective Communication with Data Visualization and Design (Indianapolis, IN: Wiley, 2014), 15, eBook.

${ }^{4}$ Eнг. Picture Superiority Effect. Према једном истраживању, испитаници су склони да након 3 дана запамте 10\% текстуалних информација, а чак 65\% информација које су комбинација текста са релевантном сликом. Овај ефекат има кључну улогу у ефектном дизајнирању инфографике, да би она испунила своју намену да изврши утицај, препоручи одређени садржај или образује публику.- Krum, Cool Infographics..., 22.

5 Ту чињеницу илуструје енормни пораст претраживања појма „инфографика” на Гуглу током периода 2010-2012. - Tufte, The visual Display of Quantitative Information, 8

${ }^{6}$ Boban Tomić, „Diskurzivno i ikoničko u novim ilustrativnim žanrovima“, CM: Communication and Media Journal 33 (2015): 107-126, preuzeto 15. 10. 2020, https://scindeks-clanci.ceon.rs/data/pdf/1452-7405/2015/1452-74051533107T.pdf, doi:10.5937/comman10-8397.

7 Istok Pavlović, "Bukvar digitalnog marketinga, Kako napraviti dobar infografik: recept za vizuelni storytelling“, 8. avgust 2016, preuzeto 29. 10. 2020, https://www.istokpavlovic.com/blog/kako-napraviti-dobar-infografik-recept-za-vizuelni-storytelling/.

8 Tufte, The visual Display of Quantitative Information.
} 
а мноштво скупова на кохерентан приказ, како би се омогућило упоређивање података, њихово откривање на неколико нивоа, од општег ка специфичном. Тафтијеве смернице су усмерене првенствено на јасноћу, прецизност, ефикасност, а највише јеgностивносй дизајнерских решења у приказивању квантитативних података, али додаје да су у ширем смислу применљиве и на комбинације речи, бројева и слика. На крају и сам Тафти указује на мањкавости концепта. У случајевима када инфографика има за циљ наговарање или рекламирање, може постојати пристрасност дизајнера при избору података и истицање оних најуверљивијих који могу да „афектирају."

У области савремене инфографике потребно је споменутии рад Рендија Крума, ${ }^{9}$ аутора једног од најпопуларнијих веб-сајтова посвећеног „науци” и уметности израде инфографика са обиљем ефектних примера. ${ }^{10}$ Према његовом мишљењу, инфографика је шири појам који, поред визуелизације статистичких података, укључује илустрације, текст и слике у један нови формат који „приповеда причу". Приповедање подразумева добро дизајнерско решење у комбиновању визуелизације података и графичког дизајна, које има карактеристичну трокомпонентну структуру: увод, лајтмотив - поруку која изазива тзв. „Аха!” реакцију и закључак, односно позив на деловање у складу са истакнутом поруком.

Савремени медијски простор обилује различитим формама и начинима пласирања инфографика: интерактивне, зумирајуће инфографике се одликују могућношћу да конзумент једним „кликом" на одређени део дође до додатних информација, оне пружају кориснику одређену контролу над приказаним подацима и на тај начин га ангажују и заинтересују у дужем временском периоду; ${ }^{11}$ анимиране инфографике карактеришу се стварањем покрета и промена у дизајну док се посматрају, нпр. повећава се стубасти графикон, мења боја или анимира лик; затим ту је видео-графика као релативно нова, али врло популарна форма због лаке примене на веб-сајтовима попут YouTube и Vimeo ${ }^{12}$ који успешно промовишу производе. Поред наведене разноликости, у раду ће пажња бити усмерена на најједноставнију и најприсутнију статичку форму из неколико разлога: лаког онлајн дељења на друштвеним мрежама са одговарајућим алаткама (Twitter, Facebook, Pinterest, Tumblr, LinkedIn), могућности штампања на папиру, чувања слике у JPG, PNG или GIF формату и приказа у PDF фајлу. Овакве графике се лако уграђују на веб-странице и у блогове и лако се деле мејлом.

За креирање и пласман инфографике постоје различите онлајн платформе. У развојним почецима оне су креиране у офлајн графичким софтверима као што су PhotoShop, Corel Draw, InDesign, PowerPoint и др. Са напретком капацитета и могућности интернета појављују се бесплатни, једноставно употребљиви и самим тим врло популарни веб-алати различитих перформанси на порталима попут Wordle.net, Pictochart, Easel.ly, Visual.lu, Venngage, Gliffy итд.

\section{Дизајнерске препоруке Рендија Крума}

„Основно правило је да би дизајн требало јасно да саопшти кључну поруку читаоцима за мање од пет секунди."13 Ренди Крум

Ренди Крум сматра да визуелизација података мора бити јединствена и утицајна и има избалансирану, ефектну структуру. Како истиче, суштина ефектно дизајниране инфографике је

\footnotetext{
${ }_{9}$ Krum, Cool Infographics...

${ }^{10}$ Cool Infographic, preuzeto 20. 10. 2020, www.coolinfographics.com.

11 Према Рендију Круму, веб-сајт дневног листа The New York Times важи за светског лидера у интерактивним инфографикама и визуелизацији података. - Krum, Cool Infographics..., 48.

12 Њихова намена је постављање, размена и преглед видео-снимака.

13 Krum, Cool Infographics..., 284. Наведено йравило иееи секунgи утемељено је на основу аналитичких извештаја током последњих пет година, а који се односе на милионске прегледе ауторовог веб-портала Cool Infographics.
} 


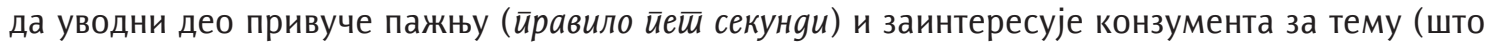
интересантнију, па чак и интригантну), да пружи јасне, једноставне опште информације пре преласка на детаље. У следећем кораку би требало да доминира визуелни део са новим ин-

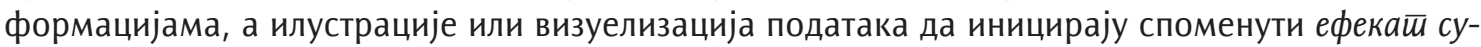
иериорносии слике, требало би да буду лако и брзо запамћени јер носе главну поенту приче. 3aвршетак би требало да буде ефектан и да представља позив на акцију или примену понуђене (пре)поруке (коришћење нове услуге, најаве дешавања, обавештење о нерадним данима, промена радног времена, број уписаних корисника, измене у коришћењу апликације за електронско поручивање грађе итд.). Крум посвећује пажњу и величини фонта слова, могућности поређења података, важности комбиновања икона, боја и графикона, истицању лога компаније.

\section{„Рецепти" за визуелни storytelling Истока Павловића}

„Добар инфографик је пре свега добра прича, лепа слика и дизајн су битни али не и пресудни. Дакле, битан је сценарио, оно што пише, начин на који тече нарација."14

Исток Павловић

Један од најутицајнијих блогера у Србији, Исток Павловић, ${ }^{15}$ познат је, између осталог по инфографици „Дигитални правопис", ${ }^{16}$ у којој обавештава и обучава конзументе о правилима писања сајбер порука. Његове смернице о стварању ефектних инфографика су првенствено усмерене на занимљивост и ток приче, а потом на добар дизајн. Он истиче да се успех постиже када се идеја „полако гради и преноси људима кроз једноставне метафоре и питку причу". Важно је да прича буди емоције код конзумента, што Павловић сликовито описује: „Прво им се укључи центар за смејање, па центар за учење, онда осете мало беса због неке неправде, па се опет насмеју, и тако даље..."17 Додатно, залаже се за употребу визуелних метафора које би требало да замене графичке форме представљања бројчаних података зване „пита” (енг. pie chart) или „стубац” (енг. bar chart). „Људи не могу да осете емоцију према табели препуној бројева. Ако покушамо да им саопштимо да неко има 10\%, а неко 17\% нечега, то није довољно директно. Али, шта је оно што свако разуме? Храна. Свако једе. И свако је био мали и разуме шта значи кад старији брат добије веће парче гибанице, а млађа сестра мање, и тако даље."

\section{Pinterest: галерија идеја за дизајнирање инфографика за библиотекаре}

„Да бисте створили моћну инфографику, сачувајте величину графике и ефектне слике. Вредно прикупљајте информације и осмислите причу која ће имати општи значај". ${ }^{18}$

Дин Мајерс, Visual Problem solver

Ради приказивања и промовисања различитих визуелних форми на вебу, креирана је друштвена мрежа Pinterest, ${ }^{19}$ на којој инфографика доминира у апсолутној мери. Pinterest

\footnotetext{
14 Pavlović, "Bukvar digitalnog marketinga...".

15 Бави се дигиталним маркетингом, један је од аутора сатиричног портала Njuz.net и аутор је редовне колумне у Полишици.

${ }^{16}$ Istok Pavlović, „Bukvar digitalnog marketinga“, Digitalni pravopis, mart 12, 2012 preuzeto 11. 11. 2020, https://www.istokpavlovic. com/blog/digitalni-pravopis/.

17 Pavlović, „Bukvar digitalnog marketinga, Kako napraviti dobar infografik: recept za vizuelni storytelling”.

18 Tufte, The visual Display of Quantitative Information, XVII.

19 Америчка компанија коју воде Бен Силберман, Пол Шиара и Еван Шарп са седиштем у Сан Франциску, пружа услуге онлајн дељења слика и друштвених медија, као и чување и откривање информација, посебно „идеја”. Функционише као бесплатан портал који захтева отварање корисничког налога. Доминантан формат су слике, а у мањем обиму анимирани GIFF-ови и видео-записи. Посећеност портала је бележила преко 400 милиона активних корисника на месечном нивоу закључно са августом 2020. - Pinterest, preuzeto 20. 10. 2020, https://www.pinterest.com.
} 
је једна од најзаступљенијих друштвених мрежа у форми веб-сајта и мобилне апликације, а према Бобану Томићу, „тематски дијапазон инфографика које се размењују и публикују је веома широк". Бавећи се пажљивим сагледавањем и анализом садржаја у домену медијског тржишта, Томић извештава о„великој тематској разноврсности, богатству података, информација и знања као темељних категорија инфографике." Сагледавањем примера упутстава и различитих едукативних инфографика о многим темама, у контексту поређења дискурзивног и иконичког наратива, на крају закључује „да се сликовитим приказом може саопштити скоро све што и лингвистичким средствима комуникације."20

Сходно својој намени, Pinterest с правом носи епитете „каталог идеја” и „визуелни претраживач". ${ }^{21}$ Куриозитет чине анализе демографских података са Википедије, према којима примат у коришћењу портала има женска популација. ${ }^{22}$ Томе вероватно доприносе садржаји попут модних трендова, рецепата, уређења ентеријера, оцена филмова, цена производа и сл. ${ }^{23}$ Од многобројних опција ове друштвене мреже требало би навести само базичне, а то су чување, сортирање и управљање сликама или „идејама” коришћењем алатке под називом "чиода" (енг. pin) и стварање личних збирки познатих као „табле” (енг. pinboard).

Оно што је значајно за овај рад односи се на претраживање инфографика из области библиотекарства. Ради се о покушају да се анализира актуелна тематика и прокоментаришу коришћени принципи и дизајнерска решења инфографика присутних у Pinterest окружењу. Специфично је да се ради о инфографикама на енглеском језику које су артикли многобројних америчких библиотека, библиотекара и дизајнера.

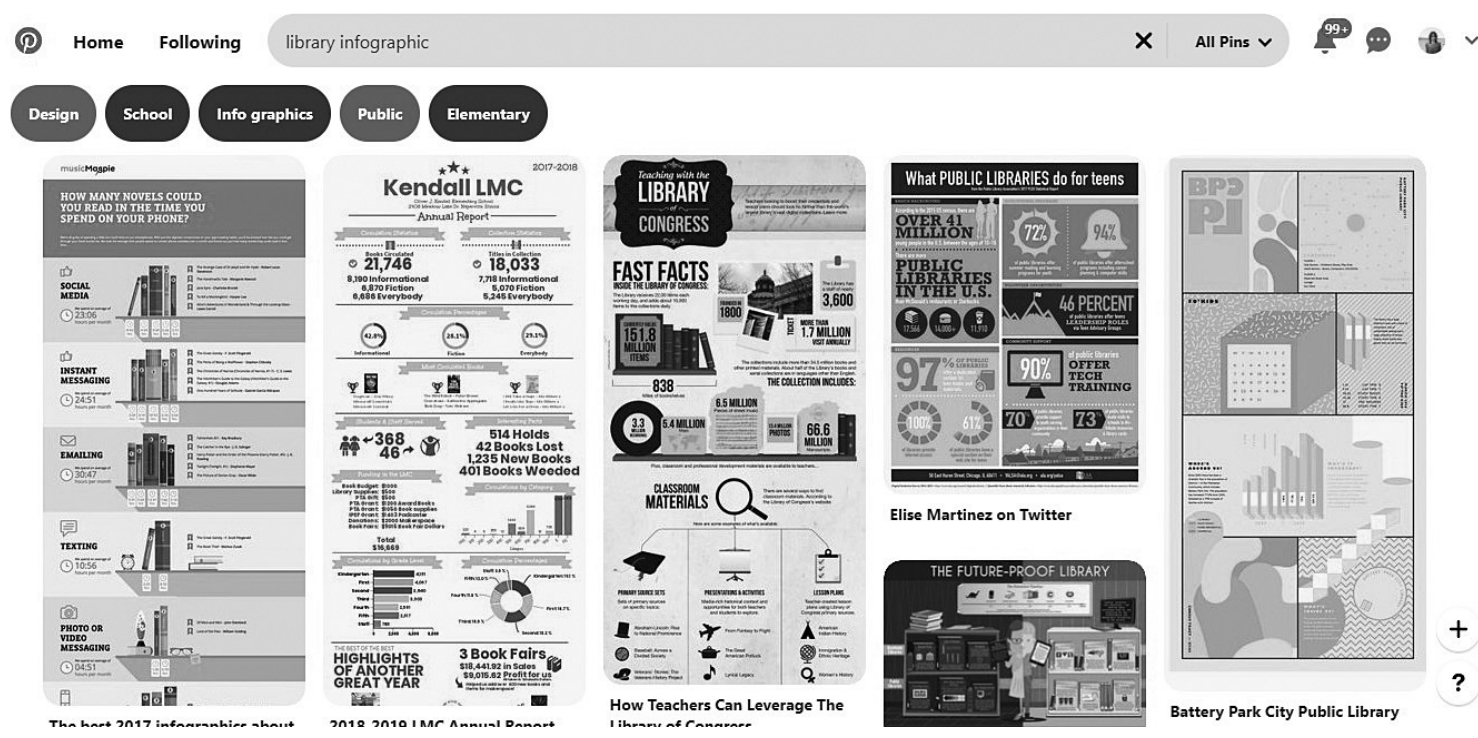

Сл. 1. Претраживање инфографика према кључним речима "library infographic" на порталу Pinterest

Општом претрагом "library infographic" по свим „чиодама" без ограничавања на понуђене поткатегорије: дизајн, школске, инфографика, јавне, основне (односи се на библиотеке) добија се импозантан број примера и графичких решења са библиотечком тематиком из свих типова библиотека (Сл. 1). Оно што отежава анализу је сам приказ инфографика без структурисања

\footnotetext{
20 Tomić, „Diskurzivno i ikoničko u novim ilustrativnim žanrovima“: 121.

21 Опција „визуелне претраге” уведена је 2017. године. Она омогућава претраживање конкретних елемената на сликама на основу постојећих „чиода", нових или појединих делова фотографија и наводи кориснике ка сличним садржајима из базе података.

22 Чак 83\% у истраживању из 2012. године. - Pinterest, preuzeto 10. 9. 2020, https://en.wikipedia.org/wiki/Pinterest.

${ }^{23}$ Janet Mayure, Teach Yourself Visually Pinterest (Indianapolis: Jon Wiley \& Sons, 2012).
} 
или категорисања садржаја, али са друге стране, он даје одличан општи преглед понуђених аспеката библиотечког деловања. Свака јединица може да се сачува у оквиру одабране, унапред дефинисане „табле”, чиме се може креирати лични избор и структура инфографика.

Сагледавањем мноштва, у йрву кайеїорију инфографика аутор је сврстао оне које представљају визуелизације статистичких података Тафтијевог типа, у којима су заступљена стубаста решења, дијаграми, и графикони. На овај начин се заправо дизајнирају годишњи извештаји библиотека са истакнутим бројчаним износима посетилаца, коришћених публикација, финансијама, новим издањима, па чак и изгубљеним књигама ${ }^{24}$ (Сл. 2). Наслови су истакнути већим једноставним фонтом без сенчења или упечатљивијих решења. Илустрације су углавном сведене, без уметничких елемената. Увиђају се прегледност, сведеност и правилна структура. Оне заправо замењују дугачке писане извештаје и на сажет, допадљив, сликовит начин обавештавају јавност о значајним пословним информацијама у складу са наведеним Крумовим ефекйом суиеериорносиии слике и правилом привлачења пажње у року од пет секунди.

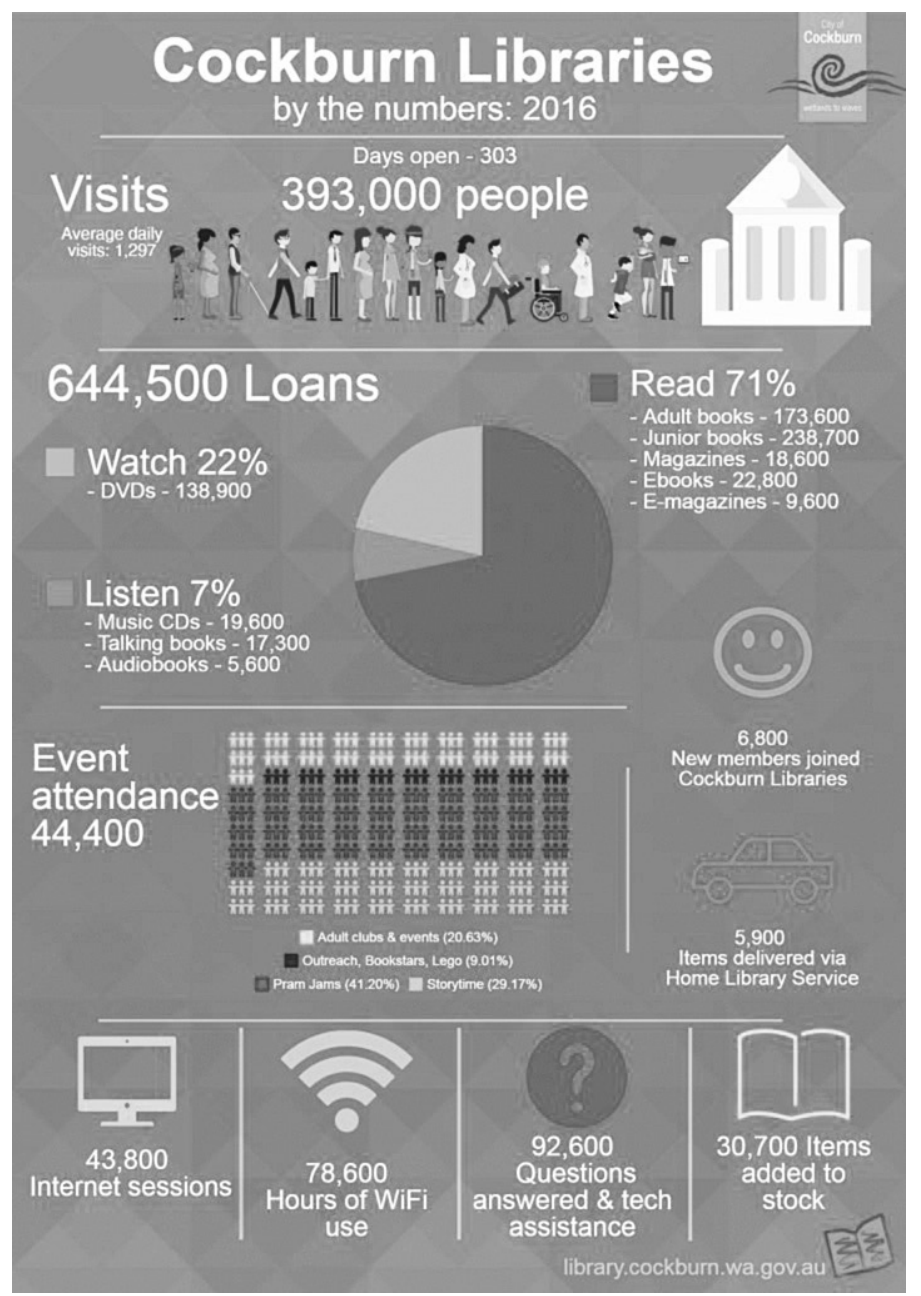

Сл. 2. Годишњи извештај библиотеке Cockburn Libraries у бројкама за 2016. годину25

\footnotetext{
${ }^{24}$ Venngage, 2018-2019 LMC Annual Report, preuzeto $11.11 . \quad 2020$, https//venngage.net/ps/ X9pcSNeCnql/2017-2018-Imc-report-kendall-elementary-naperville-il.

25 Jenni D., "2016 has been a big year for Cockburn Libraries, the numbers are impressive", Jan 30 th 2017, preuzeto 1. 11. 2020, https://www.cockburnlibraries.com.au/blog/infographic-cockburn-libraries-2016-numbers/.
} 
У gруїу кашеті̄орију која, према аутору, заслужује пажњу, спадају различита упутства и инструкције у едукативне сврхе. Корисни су, на пример, за информационо описмењавање студената ${ }^{26}$ (Сл. 3) у облику сликовито и структурирано приказаних фаза тражења извора и алата, евалуације података, цитирања литературе итд. Пажњу привлаче јарке боје којима су истакнути кораци у процесу подучавања, а кратке напомене су уоквирене и тиме чине мале, лако уочљиве целине.

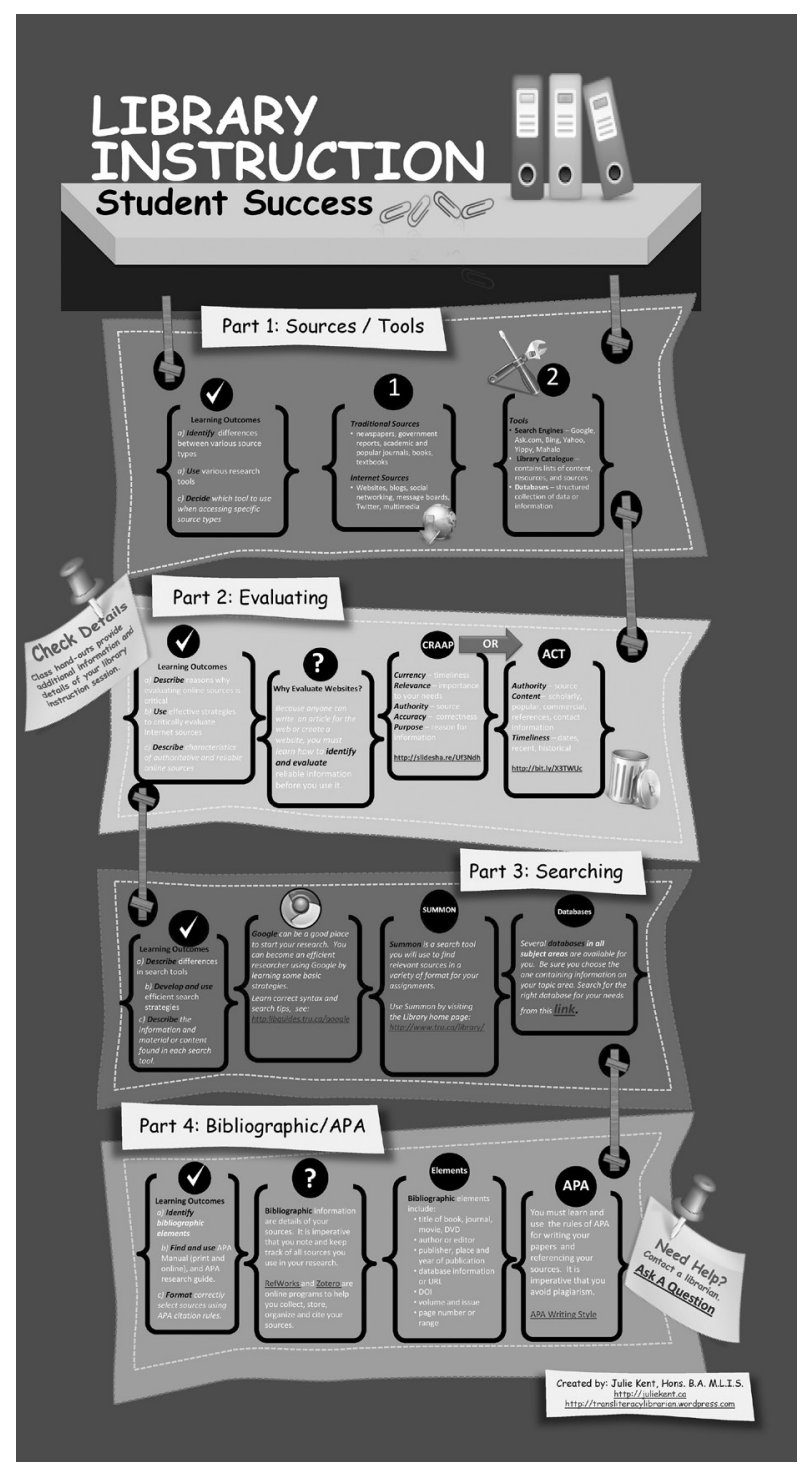

Сл. 3. Упутство по фазама из информационе писмености за студенте

Инфографика као едукативно средство је постојала 30-40-тих година 20. века и постоји серија тзв. "vintage" инфографика које се могу пронаћи путем претраге "library infographic vintage". Представљају добар пример визуелне комуникације у едукацији из прошлости. Као

\footnotetext{
${ }^{26}$ On Being a Librarian: Trends, Achievements and Perspectives, Infographics \& Information Literacy, preuzeto 1. 11. 2020, https:// transliteracylibrarian.com/2013/02/09/infographics-information-literacy/.
} 
наставна помагала, на њима се могу видети упутства за претраживање лисног каталога ${ }^{27}$ (Сл. 4). Структура овог плаката јасно показује да постоје три начина претраживања: према аутору, наслову и предмету, додатно илустрованих примерима каталошких листића, као и упућивање на сигнатуру и упрошћени децимални систем. Запажа се употреба сйрелица као сликовног везивног елемента. На наведеном блогу Оле Ковалчик може се пронаћи још неколико интересантних плаката, а на једном од њих је представљена структура знања у облику разгранатог дрвета налик „мапама ума”, које у новије доба промовише Тони Бузан. ${ }^{28}$

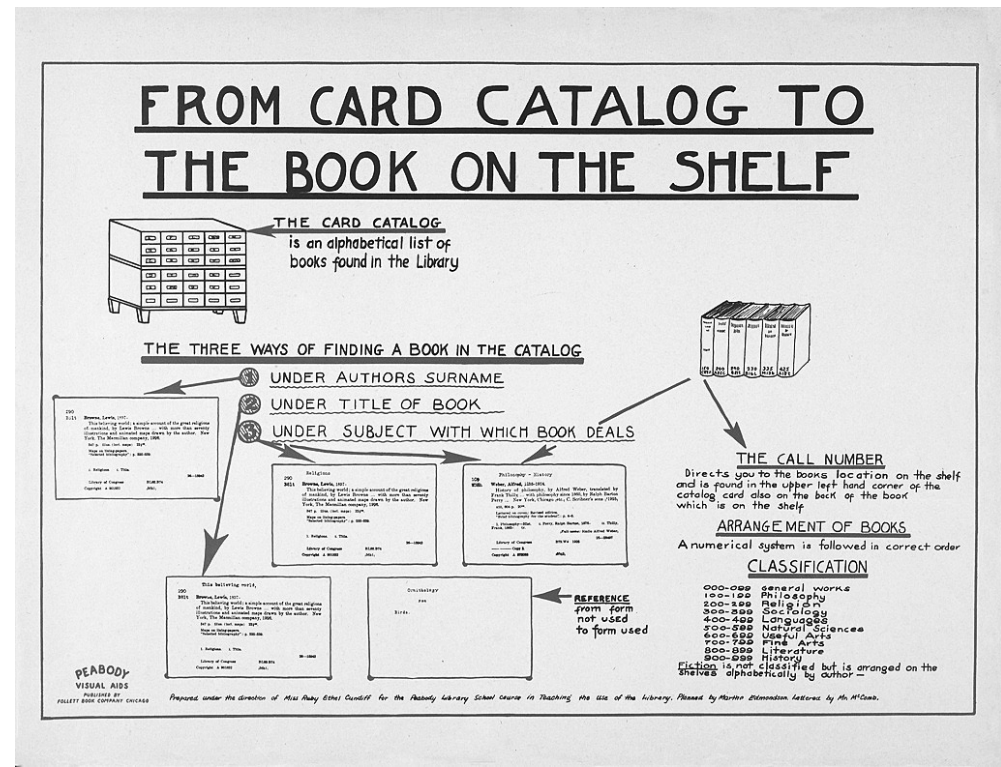

Сл. 4. Ннфографика са ситрелиияама као едукативно средство за употребу лисног каталога

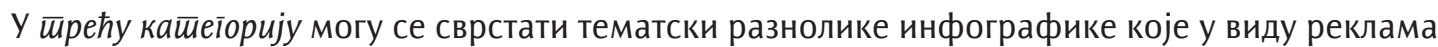
или огласа указују на различите аспекте, позитивне или негативне појаве у библиотекарству. На пример, појава плагијаризма ${ }^{29}$ и промовисање правила заната академског писања и етике представљенису кроз оригинално „приповедање” на инфографици на Сл. 5. На тему плагијаризма поентира планетарно позната књижевница Џоана К. Роулинг. Ради се о необичној и ефектној комбинацији њених ӣорука везаних за одрастање и однос деце према родитељима праћених одговарајућим стручним репликама везаним за цитирање, парафразирање, научну етику итд. Поред тога, доживљај употпуњују популарни ликови из филмова снимљених на основу ауторкиних књига о Харију Потеру. Текстуалне поруке су кратке, ефектне, са дозом хумора. Једна од анегдота са инфографике гласи: „Према Џоани К. Роулинг, своје родитеље можете окривљавати све док не стекнете возачку дозволу”, а реплика гласи „то баш и није прави плагијаризам, али је неистинито представљање извора непоштено на Сиријусов начин."30

\footnotetext{
27 Занимљиво је истаћи да је инфографике (плакате) на овом сајту пронашла Шар Бут (енг. Char Booth), управница библиотеке California State University San Marcos, међу грађом за отпис и дала их да се дигитализују. Дизајнирала их је компанија Реabody Visual Aids по решењу библиотекарке Руби Етел Кандиф (енг. Ruby Ethel Cundiff). - Ola Kowalczyk, "10 Vintage Library Infographics from the 30s and 40s (pictures)", updated on September $27^{\text {th }}$ 2018, preuzeto 20. 10. 2020, https://ebookfriendly.com/ vintage-library-infographics/.

28 (Енг. Anthony Peter "Tony“ Buzan) је енглески писац и едукатор који се бави проучавањем неуропсихолошких процеса у мозгу, семантиком и памћењем. Познат је по пропагирању техника менталне писмености као што су "мапе ума" и брзо читање.

29 A. Imgur, Magical Guide to Avoiding Plagiarism, preuzeto 20. 10. 2020, https://imgur.com/a/MkZDy.

30 (Енг. Sirius Black) је лик из књиге Хари Пошеер и зашевореник из Аскабана, у којој је приказан као убица, издајица и мрзитељ својих родитеља.
} 


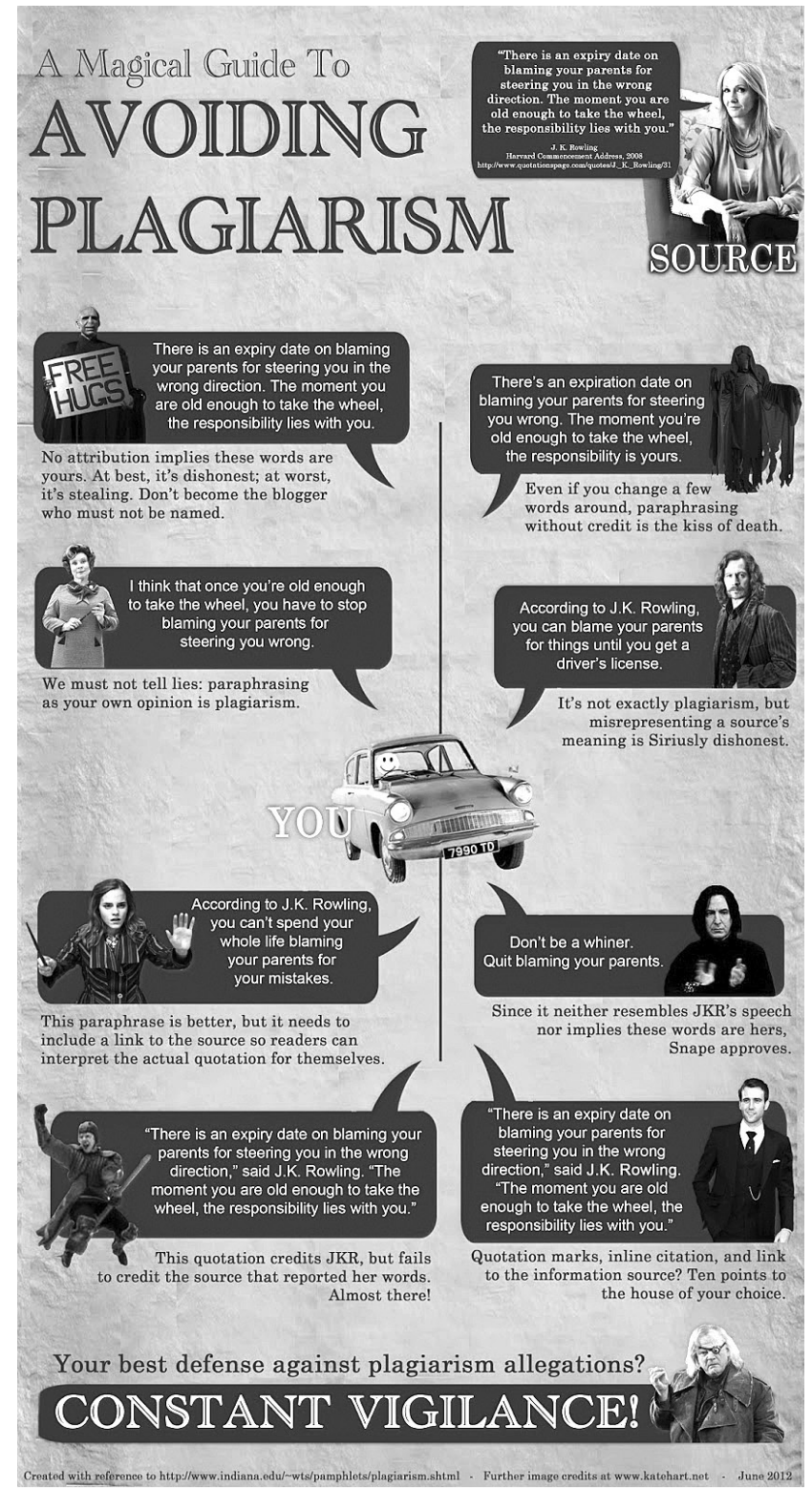

Сл. 5. Џоана К. Роулинг и јунаци из Харија Потера у „магичној” борби против плагијаризма

Следећа инфографика приказује једну комплексну услугу Конгресне библиотеке у Вашингтону која представља значајан аспект сараgње библиотеке са наставним особљем и сам процес осмишљавања наставе у школама ${ }^{31}$ (Сл. 6). Наиме, ова библиотека нуди наставницима програме за стручно усавршавање, даје им на јавно коришћење разнолику грађу из својих богатих дигиталних збирки (нотни записи, мапе, планови предавања, рукописи, говори, есеји и др.) и предочава начине на које се грађа може пронаћи и користити. Инфографика представља елегантно дизајнерско решење, са дискретним бојама, укусно одабраним фотографијама и илустрацијама. Садржај је лако пратити по секцијама.

\footnotetext{
${ }^{31}$ Teacher infographic, How Teachers Can Leverage The Library of Congress Infographic, preuzeto 20. 10. 2020, https://elearninginfographics.com/teachers-can-leverage-the-library-of-congress-infographic/\#sthash.fPCvrr6q.qjtu.
} 


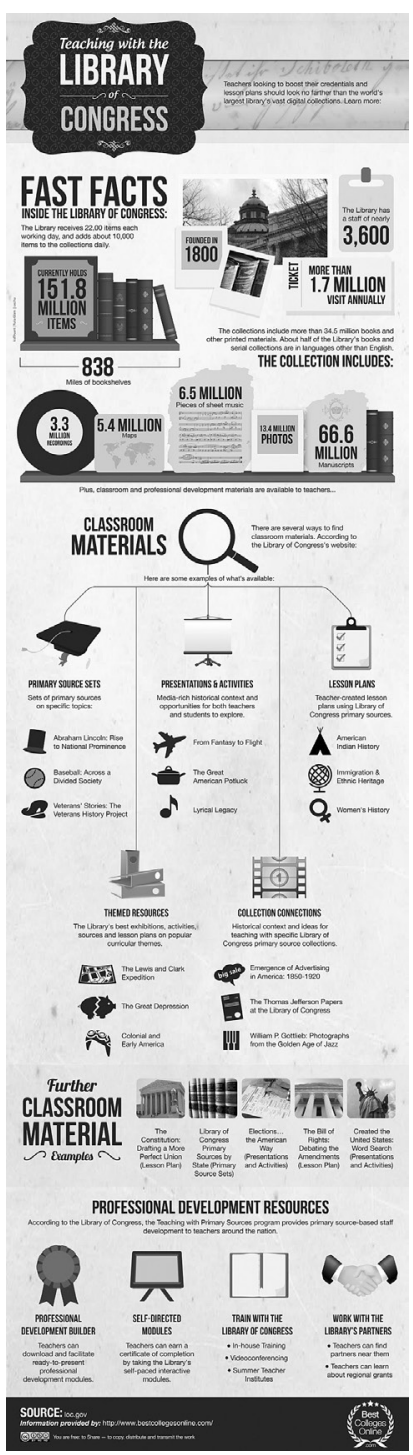

Сл. 6. Инфографика која промовише сарадњу библиотеке са школама

Последња одабрана инфографика промовише технику „пажљивог читања" (енг. close reading $)^{32}$ са намером да приближи деци да се темељно баве оним што читају, постављањем питања о ономе што примећују у тексту и тражењем одговора на та питања (Сл. 7). Њени најистакнутији мотиви су визуелно ефектан и метафоричан наслов "Читај као детектив", као и атрактивна илустрација типичног детектива обученог у мантил, са шеширом на глави и великом лупом у руци кроз коју посматра свет. Структура текста је прегледна, истичу се квалитети ове технике читања кроз ефекат поређења и разликовање оних који примењују технику, а који не. Наводе се и кратке тезе о стандардима технике. Наглашена су питања која је потребно постављати док се пажљиво чита уз елемент светиљке која алудира на „просветљење." На крају су наведене смернице за учитеље за подучавање ове технике.

\footnotetext{
${ }^{32}$ We are teachers, ideas, inspiration, and Giveaways for Teachers, Understanding Close Reading:Download our Infographic Now!, on January $8^{\text {th }}$ 2014, preuzeto 20. 10. 2020, https://www.weareteachers.com/understanding-close-reading-download-our-infographic-now/.
} 


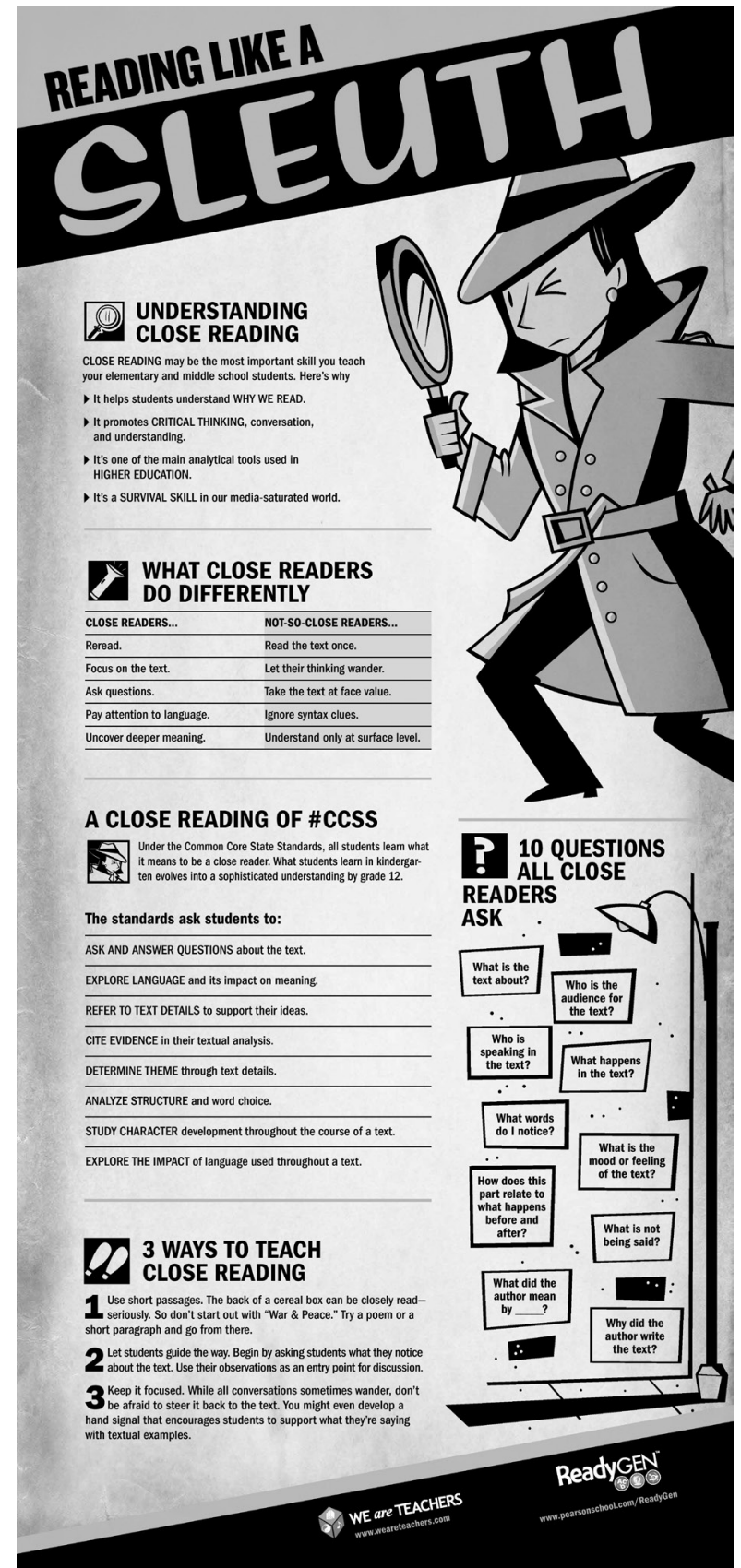

Сл. 7. Промовисање „пажљивог читања"

Дакле, анализом инфографика на Pinterest порталу везаних за библиотекарску струку, може се рећи да су идеје, темеи дизајнерска решења за различите библиотечке потребе многобројне, оригиналне и врло информативне и могу помоћи библиотекарима у побољшању рада или увођењу новина. Од мноштва понуђене грађе, издвојене су три категорије: приказивање статистичких података по угледу на Тафтија, различита упутства и инструкције у образовне сврхе, као и рекламе и огласи који указују или информишу о различитим темама и појавама у библиотекарству. Критеријуми за избор ограничени су на личне преференције, ефекат занимљивости, новине појаве, допадљивости на први поглед (иравило йей секунgu). 


\section{Закључак}

„Циљ уметности није представљање спољашњег изгледа ствари већ њиховог унутрашњег значаја."33

Аристотел

Популарност инфографике у свим областима друштвених и природних наука, па и шире, у којима је потребна визуелизација података и приповедања, непрестано расте. Са порастом информација на интернету и насушном потребом за њиховим филтрирањем, инфографски дизајн је један од најбољих алата који установама омогућава дељење и саопштавање информација у облику дигиталних или штампаних производа. Као таква, инфографичка решења у једној библиотеци могу бити постављена на званични веб-сајт, друштвену мрежу библиотеке, пружена у руке корисника у облику флајера како би објаснила неку новину, рекламирала ново издање, могу бити одштампана на платну великог формата и постављена на адекватном месту, окачена на слободном зиду, постављена у виду плаката на сесији конференције... Могућности су бескрајне. Може се слободно рећи да је инфографика својеврсна наука са својим постулатима, сложени спој уметничког дизајна, емпиријске статистике и математике, како је сматрао Тафти. Ради подстицања библиотекара за њено коришћење, у раду су истакнуте смернице за ефектно приказивање и дизајнирање података и приповедање. Тафтијеве смернице су усмерене првенствено на јасноћу, прецизност, ефикасност, а највише јеgноставност дизајнерских решења у приказивању квантитативних података. Ренди Крум сматра да визуелизација података мора бити јединствена и утицајна и има избалансирану, ефектну структуру: увод, лајтмотив поруку која изазива тзв. "Аха!" реакцију и закључак, односно позив на деловање у складу са истакнутом поруком.

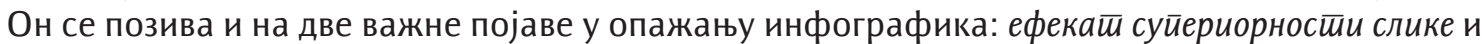
иравило иеей секунgи. Исток Павловић, пак, истиче важност занимљивости приче и тока њеног приповедања, изазивања емоција код конзумента, као и употребу визуелних метафора ради лакшег конзумирања.

Идеје за дизајнерска решења инфографика за библиотекаре су истражене на друштвеној мрежи Pinterest. Без залажења у озбиљне анализе садржаја, инфографике су изабране и описане на основу личних преференција, занимљивости теме, ефектности, допадљивости дизајна, али и информативности и важности тема којима се баве библиотекари у Америци. Прво је одабрано једно графичко решење годишњег извештаја са статистичким подацима библиотеке Cockburn Libraries из разлога што се таквим решењима у Србији не придаје значај, а затим ефектна и прегледна шема фаза процеса информационе писмености за студенте. Као куриозитет се учинио плакат из 30-40-тих година 20. века, који је, заједно са још десетак, пронашла управница библиотеке California State University San Marcos. Учинило се занимљивим показати времешну, једноставну и ефектну шему за коришћење лисног каталога, са одредницама и децималном класификацијом. Највеће одушевљење аутору је изазвало приповедање о борби против плагијаризма у које су укључени веома популарна ауторка Џоана К. Роулинг и ликови из серијала о Харију Потеру. Инфографика Конгресне библиотеке у Вашингтону је одабрана са циљем истицања значајног аспекта сарадње библиотека са наставним особљем, њиховим стручним оспособљавањем у осмишљавању наставе и коришћења библиотечке грађе, што је за српске прилике реткост. Последње изабрана је инфографика са веб-сајта намењена наставницима, а ради се о подучавању техници „пажљивог читања", која може бити подједнако значајна библиотекарима и читаоцима, а притом је допадљивог дизајна.

\footnotetext{
${ }_{33}$ Roman A. Valiulin, NMR Multiplet Interpretation: an infographic walk through (Boston: Walter De Grynter, 2019), [V]
} 
Дакле, инфографике су ту да привуку пажњу, комбинацијом текста и слике представе много података, испричају причу о услузи или опомену на непримерене појаве и понашање, али и „раде” на репрезентативности библиотеке. За њихово дизајнирање можда и није потребан професионални дизајнер, с обзиром на ограничено финансијско стање српских библиотека, док са друге стране постоје бесплатни портали и софтвери за стварање визуелних креација. Идеје се могу потражити на Pinterestu, који нуди обиље фасцинантних решења. Стварање инфографике може бити оригиналан, забаван, уметнички чин, видљив, ефектан и користан за маркетинг у свакој библиотеци. Зато је ово позив да се на визуелан, креативан начин покуша повећати утицај, побољшати квалитет услуга и остварити бољи утисак библиотечке струке у друштву. У духу визуелног приповедања, може бити предлог да се, попут оне праисторијске графичке приче о начину „како успешно уловити антилопу”, покуша са приповедањем једне савремене библиотечке о начину „како привући и ефектно образовати наше кориснике”.

\section{Литература и извори:}

1. Cool Infographic. Preuzeto 20. 10. 2020. www.coolinfographics.com.

2. D., Jenni. " 2016 has been a big year for Cockburn Libraries, the numbers are impressive". Jan 30 th 2017, preuzeto 1. 11. 2020. https://www.cockburnlibraries.com.au/blog/ infographic-cockburn-libraries-2016-numbers/.

3. Hofschire, Linda. "Let's Get Visual: Harnessing data visualization to demonstrate a library's impact". November $1^{\text {st }} 2016$, preuzeto 19. 10. 2020. https://americanlibrariesmagazine.org/2016/11/01/ lets-get-visual-data-visualization/.

4. Imgur, A. Magical Guide to Avoiding Plagiarism. Preuzeto 20. 10. 2020. https://imgur.com/a/MkZDy.

5. Kowalczyk, Ola. "10 Vintage Library Infographics from the 30 s and 40 s (pictures)". Updated on September $27^{\text {th }} 2018$, preuzeto 20. 10. 2020. https://ebookfriendly.com/vintage-library-infographics/.

6. Krum, Randy. Cool Infographics: Effective Communication with Data Visualization and Design. Indianapolis, IN: Wiley, 2014. eBook.

7. Mayure, Janet. Teach Yourself Visually Pinterest. Indianapolis: Jon Wiley \& Sons, 2012.

8. On Being a Librarian: Trends, Achievements and Perspectives. Infographics \& Information Literacy. Preuzeto 1. 11. 2020. https://transliteracylibrarian.com/2013/02/09/infographics-information-literacy/.

9. Pavlović, Istok. „Bukvar digitalnog marketinga“. Digitalni pravopis. Mart 12, 2012, preuzeto 11. 11. 2020. https://www.istokpavlovic.com/blog/digitalni-pravopis/.

10. Pavlović, Istok. „Bukvar digitalnog marketinga, Kako napraviti dobar infografik: recept za vizuelni storytelling“. 8. avgust 2016, preuzeto 29. 10. 2020. https://www.istokpavlovic.com/blog/ kako-napraviti-dobar-infografik-recept-za-vizuelni-storytelling/.

11. Pinterest. Preuzeto 20. 10. 2020. https://www.pinterest.com.

12. Pinterest. Preuzeto 10. 9. 2020, https://en.wikipedia.org/wiki/Pinterest.

13. Teacher infographic. How Teachers Can Leverage The Library of Congress Infographic. Preuzeto 20. 10. 2020. https://elearninginfographics.com/teachers-can-leverage-the-library-of-congress-infographic/\#sthash.fPCvrr6q.qjtu.

14. Tomić, Boban. „Diskurzivno i ikoničko u novim ilustrativnim žanrovima“. CM: Communication and Media Journal 33 (2015): 107-126. Preuzeto 15. 10. 2020. https://scindeks-clanci.ceon.rs/data/pdf/14527405/2015/1452-74051533107T.pdf, doi:10.5937/comman10-8397.

15. Tufte, Edward R. The visual Display of Quantitative Information. Cheshire, Connecticut: Graphic Press, 2001. Preuzeto 15. 10. 2020. http://www.edwardtufte.com/.

16. Valiulin, Roman A. NMR Multiplet Interpretation: an infographic walk through. Boston: Walter De Grynter, 2019.

17. Venngage. 2018-2019 LMC Annual Report. Preuzeto 11. 11. 2020, https//venngage.net/ps/ X9pcSNeCnql/2017-2018-Imc-report-kendall-elementary-naperville-il. 


\title{
Infographics or Visual Storytelling: Perspectives in Librarianship
}

\begin{abstract}
Summary
The paper analyzes and emphasizes the advantages of infographics, an increasingly influential technique for visual summarization of statistical data, advertising, education, and graphic storytelling of various stories with socially responsible topics. The characteristics of the modern cyber environment in which infographics have found a noticeable application are highlighted: the overflow of users with different information, the need to summarize them and the dominance of the visual over the textual narrative, as well as the physiological functioning of the brain system, which is characterized by the dominance of the sense of sight and more efficient memory of picture than text called the picture superiority effect. The application of infographics in librarianship is considered through the descriptions of several selected examples of infographics that effectively represent specific aspects of library work on the Pinterest portal. First, the graphical solution of the statistical annual report is presented, then a step-by-step guide to information literacy for students, guidance on using the card catalog from the 1930s, and finally posters pointing to plagiarism, promotion of cooperation between libraries and teachers, and a useful technique called close reading. For librarians who are interested in infographic design, guidelines have been offered for creating effective solutions in the opinion of three experts: Edward Tufte, Randy Krum, and Istok Pavlović. The guidelines refer to the clarity, precision, effectiveness and simplicity of design solutions, the structure and intriguingness of the story, as well as attracting attention (the 5-second rule), evoking emotions, and the use of visual metaphors. The necessary tools and free design platforms are also indicated. The aim of this paper is to encourage librarians to think about the visual motifs of representativeness and library marketing, to be creative and above all authentic.
\end{abstract}

Keywords: data visualization, data compression, static infographics, visual narration, design guidelines, Pinterest, content analysis, annual statistical report, information literacy, use of card catalogue, plagiarism, cooperation between libraries and teachers, close reading, visual library marketing, creativity 